\title{
THE SCIENTIFIC-METHODOLOGICAL STUDY OF A PAPER TO OBTAIN THE FIRST TEACHING DEGREE
}

\author{
LEON BUZILĂ \\ Teacher, "Iacob and Ioachim Mureşanu" Secondary School Rebrişoara, Bistriţa-Năsăud County, Romania, \\ e-mail: leonbuzila@yahoo.com.

\section{MARIA-ELIZA DULAMĂ} \\ Associate professor, Babeş-Bolyai University, Faculty of Psychology and Sciences of Education, Cluj- \\ Napoca, Romania, e-mail: dulama@upcmail.ro.
}

\section{SANDA-RAVECA BUZILĂ}

Pre-school and primary school teacher, "Iacob and Ioachim Mureşanu" Secondary School Rebrişoara, Bistriţa-Năsăud County, Romania, e-mail: sandabuzila@yahoo.com.

(Received: June 2014; in revised form: July 2014)

\begin{abstract}
In the first part of the paper, I analyzed the content of the scientific-methodical paper for obtaining the first teaching degree with the title "The Touristic Potential of the Gersa Valley and Its Exploitation" and the presentation of pedagogical research which involved the students. The research described was conducted in the school year 2013-2014 at the "Iacob and Ioachim Mureşanu" Secondary School in Rebrişoara, Bistriţa-Năsăud County, Romania. A practical, quantitative pedagogical research, with an observation and an experimental phase was organized. The research paradigm was constructivism. The research strategy was action- research.
\end{abstract}

Keywords: action-research, extracurricular activity, pedagogical research, preuniversity education, test, evaluation criteria

\section{INTRODUCTION}

This study was based on the finding that secondary school teachers have some difficulties in developing the methodological part of the work to obtain the first teaching degree, in devising and doing pedagogical research. Since 
we are interested to offer support to teachers of geography, we present some aspects regarding the content of the paper, the devise and organization of the research.

The objectives of this study were as follows:

1) the scientific-methodological analysis of the paper to obtain the first teaching degree "The Touristic Potential of the Gersa Valley and Its Exploitation";

2) analyzing the presentation of the pedagogical research in which students were involved.

\section{THEORETICAL SUBSTANTIATION}

Currently, obtaining the first teaching degree in secondary education was done according to the Law of National Education 2011, Order no. 5561 from October 2011 for approving the Methodology regarding the training of school education staff (2011) and the Appendix to this order: "Methodology from 7 October 2011 on the training of school education staff".

In Art. 35 (3) from this methodology it is stated that "the scientificmethodical thesis is developed under the guidance of a scientific leader designated by the institution - training center - which organizes the exam. The scientific leader can be a professor, an associate professor or a lecturer, having the specialty in which the candidate sits the exam." It is noted that (4) "the designation of the scientific leaders is made by the training center, according to two criteria: a) the correspondence between the thematic area of the scientific and methodical work and the remit of the coordinator; b) the written option of the candidates, the maximum number of coordination papers approved by the training center for each coordinator teacher"; (2011, p. 13).

Regarding the candidate, it is stressed that (6) "he or she has an obligation to cooperate with the coordinating professor throughout the development work"; otherwise, the coordinating professor has the right not to give his/her written opinion for submitting the work". Paragraph (7) mentiones "the obligation of the scientific leaders to provide methodological advice to the candidates they coordinate in the process of developing the necessary scientific work and provide benchmarks for monitoring and selfevaluation of their degree to which the work meets the quality standards" (2011, p. 13). Paragraph (8) states that "the liability for the content and quality of the scientific methodological work"; "for legal compliance and ethics on scientific creation and copyright lies with the candidate and the scientific leader". (10) The main criteria for the design and evaluation of the methodological and scientific work to obtain the first teaching degree are presented in Appendix 13 to this methodology (2011, p. 14). The elaboration and evaluation criteria of the methodical and scientific work to obtain teaching 


\section{THE SCIENTIFIC-METHODOLOGICAL STUDY OF A PAPER TO OBTAIN THE FIRST TEACHING DEGREE}

degree I are presented in Table 1 . In this research, we aimed to evaluate the work based on some of these criteria.

Table 1. The elaboration and evaluation criteria of the methodical and scientific work to obtain the teaching degree I

\begin{tabular}{|c|c|}
\hline $\begin{array}{c}\text { Domains/ } \\
\text { Criteria }\end{array}$ & Indicators \\
\hline I. Topic & $\begin{array}{l}\text { - The importance of the theoretical and practical approach of the topic } \\
\text { - The rigour and the accuracy of the problem demarcation } \\
\text { - Addressing an issue of major concern for school practice or for the } \\
\text { knowledge about some educational phenomena }\end{array}$ \\
\hline $\begin{array}{l}\text { II. Scientific } \\
\text { Research }\end{array}$ & $\begin{array}{l}\text { - Opportunity of bibliography and timeliness in relation to the theme } \\
\text { - Recentness of information } \\
\text { - Information processing } \\
\text { - Correct bibliographic citation of sources } \\
\text { - Recording the bibliography, according to the methodological standard }\end{array}$ \\
\hline $\begin{array}{l}\text { III. Working } \\
\text { hypothesis } \\
\text { (hypotheses) }\end{array}$ & $\begin{array}{l}\text { - Clear and correct identification and formulation of what we intend to } \\
\text { demonstrate in this paper, depending on the type of research } \\
\text { (observational, experimental, orientated, operational etc.) }\end{array}$ \\
\hline IV. Structure & $\begin{array}{l}\text { - The agreement of the structure with the theme } \\
\text { - Delimitation of the conceptual framework and theoretical basis of the } \\
\text { theme } \\
\text { - The logical sequence of chapters and subchapters } \\
\text { - The unitary character of the work and of each chapter } \\
\text { - The share of practical aspects } \\
\text { - The proportion of the parts of the paper }\end{array}$ \\
\hline V. Contents & $\begin{array}{l}\text { - Theoretical basis (scientific, psychological, pedagogical, sociological, } \\
\text { philosophical, etc.) of the issue being addressed, framing the topic in } \\
\text { pedagogical theory } \\
\text { - Linking of the organization and methodology to the specific work } \\
\text { (based on ameliorative experimental research, observational- } \\
\text { ameliorative, orientated, operational, synthesis papers, monographs, } \\
\text { etc.) } \\
\text { - Systematic character, with clear objectives, of the paper } \\
\text { - Logical and chronological order of investigation or of paper } \\
\text { - Representativeness of testing and inspection teams } \\
\text { - Rigour and value of experiments and/or observations to verify the } \\
\text { hypothesis } \\
\text { - Recording, measurement and presentation of rigorous scientific } \\
\text { collected data } \\
\text { - Data processing and correlation }\end{array}$ \\
\hline
\end{tabular}


LEON BUZILĂ, MARIA-ELIZA DULAMĂ, SANDA-RAVECA BUZILĂ

\begin{tabular}{|l|l|}
\hline & - Evaluation and comparison of initial and final results (pretest and \\
posttest) & - Correct interpretation of results \\
- Clear wording of the conclusion of the work (confirming or refuting the \\
hypothesis or the working hypothesis) \\
- Applicability of the results of the work \\
- Author's personal contribution \\
- Organic connection of the paper conclusions with the contents \\
- Opportunity of proposals and perspectives brought by the author \\
- Clarity of evidence and data presented in the annex \\
- Their correlation with tackling the problem \\
\hline VI. Form & $\begin{array}{l}\text { - Style and presentation } \\
\text { - Accuracy } \\
\text { - The layout, emphasis in text, illustrations, tables, graphs } \\
\text { - Compliance with the conditions of data editing (TNR 12, A4, line } \\
\text { spacing } 1.5 \text { lines, margins top, down, right } 2.5 \mathrm{~cm}, 3 \mathrm{~cm} \text { left) }\end{array}$ \\
\hline
\end{tabular}

\section{MATERIAL AND METHOD}

The contents of the paper. We analyzed the following materials: the contents of the methodical and scientific work to obtain the teaching degree I with the title "The Touristic Potential of the Gersa Valley and Its Exploitation"; presentation of the conducted pedagogical research.

Participants. In the design and organization of the pedagogical research, in the collection, analysis and data processing, the teacher Leon Buzilă was involved. In the activity of analyzing the contents of the research the first and the third author were involved.

Research methods. As a method of collecting data, we used the collection of texts. To analyze the texts, we used the contents analysis method, enumerative analysis and subjective analysis (Băban, 2002).

\section{RESULTS}

1) The plan of the methodical and scientific work to obtain the teaching degree I "The Touristic Potential of the Gersa Valley and Its Exploitation" 
Introduction

Chapter 1: The physical geographical individualization of the Gersa Valley

1.1. The location of the Gersa Valley and its relations with the surrounding geographical units

1.2. Geology elements of the Gersa Valley

1.2.1. Paleogeographic evolution

1.2.2. The geology of the region (stratigraphy, petrography, tectonic)

1.3. Morphometric and morphologic features of the Gersa Valley

1.3.1. Morphographical and morphometric indices of relief

1.3.2. Morphological features and geomorphological units of the region

\section{Chapter 2. Physical-geographical factors}

2.1. The petrographic factor

2.2. The climatic factor

2.2.1. Air temperature

2.2.2. Rainfall

2.2.3. Movements of air masses

2.3. The hydrological factor

2.3.1. Runoff

2.3.2. Underground leaking

2.4. Biopedogeographic factors

2.4.1. Vegetation

2.4.2. Fauna

2.4.3. Soils

\section{Chapter 3. The anthropic factor}

3.1. Infrastructure of the Gersa Valley - favourable and inhibited touristic premises

3.1.1. Means of communication

3.1.2. Accomodation

3.1.3. Communication infrastructure

3.2. Ethno-cultural elements

3.2.1. Houses and cuisine in Gersa

3.2.1.1. Traditional houses in Gersa

3.2.1.2. Traditional cuisine in Gersa

3.2.2. Folk costumes

3.2.3. Customs and traditions in the Gersa Valley

3.2.3.1. Customs related to birth

3.2.3.2. Customs related to weddings

3.2.3.3. Customs related to funerals 
3.2.3.4. Customs related to Christmas, the New Year and Easter

3.2.3.5. Other customs in the Gersa Valley

3.2.4. Rebrişoara Ethnographic Museum

3.2.4. The Heroes Monument

3.2.4. Memorial Houses

3.2.4.1. "Iacob Mureşanu" Memorial House - a people`s desire in Rebrişoara

3.2.4.2. Iacob and Ioachim Mureşanu - nation-wide personalities

3.2.4.2.1. Iacob Mureşanu

3.2.4.2.2. Ioachim Mureşanu

3.3. Religious sights

3.3.1. "Sfinţii Arhangheli Mihail şi Gavril" Orthodox Church, Rebrişoara

3.3.2. The old wooden church in Grui

3.3.3. The new church in Grui

3.3.4. The church in Gersa I (Dobodea)

3.3.5. Pentecostal Church "BETEL" Rebrişoara

3.3.6. The Pentecostal Church in Gersa I (Dobodea)

3.4. Characteristic crafts

3.4.1. Water mills

3.4.2. Whirlpools

3.4.3. Brandy Boilers (of "jinars")

3.4.5. The circular

3.4.6. The saw mill

Chapter 4. Solutions for tourism development in the valley (examples)

4.1. Designing and building a campsite

4.2. Promoting tourism in the media and on the Internet

Chapter 5. Methodical applications on "The Touristic Potential of the Gersa Valley and Its Exploitation"

5.1. The need for studying with students the touristic potential

5.2. Training students 'skills by studying the local touristic potential

5.3. Research objectives

5.4. Research hypothesis

5.5. Research variables

5.6. Major coordinates of the research

5.6.1. The place of research

5.6.2. Research period

5.6.3. The sample of subjects

5.6.4. Sample Content

5.7. Research methodology

5.8. Observational research stage 
5.8.1. Research objectives in the observational stage

5.8.2. Applying the initial test

5.8.3. Analyzing the results obtained in the initial test

5.9. Presentation of experimental activities

5.9.1. Learning activities on the topic "touristic potential of the relief in the Gersa Valley"

5.9.2. Learning activities on the topic "touristic potential of the karstic relief - Izvorul Tăuşoarelor cave"

5.10. Research in the post experimental stage

5.10.1. Research objectives in the observational stage

5.10.2. Applying the final test

5.10.3 Analyzing the results obtained in the final test

5.11. Examples of optional subjects for future school years

5.11.1. Designing an annual planning

5.11.2. Designing a unit planning

Chapter 6. Conclusions

References

\section{2) Presentation of observational and experimental research}

Motivation of the research. We conducted the research on the assumption that, for the exploitation of the touristic local horizon it is necessary that the students know it first. They can analyze this potential directly, especially in the extra-curricular activities. Indirectly, the students can persuade their families to better exploit this rich and valuable touristic potential.

The research objectives were the following: evaluation and assessment of students ' knowledge about the touristic potential of the Gersa Valley; the design, organization and analysis of the learning activities with the students on the touristic potential of the Gersa Valley; the design and analysis of an optional course entitled "The Touristic Potential of the Gersa Valley", in the annual planning and of the unit planning.

The research hypothesis was the following: the students from the fifth grade can gain good quality knowledge about the Gersa Valley through their involvement in the leal on the field.

The research variables. The independent variable is represented by the learning activities in which the students are involved. The dependent variable is representd by the students ' achievement regarding the touristic potential of the Gersa Valley. 
The place of research. The research took place at "Iacob şi Ioachim Mureşanu" Secondary School, in Rebrişoara, Bistriţa-Năsăud County.

The research period. The research was conducted in the 2013-2014 school year.

The subjects of research. The experimental group consisted of five girls and five boys in the fifth grade from "Iacob and Ioachim Mureşanu" Secondary School in Rebrişoara, who participated in extracurricular activities in the local horizon. In the research, teacher Leon Buzilă was involved, as a teacher and researcher.

The sample contents included: the touristic potential of the relief of the Gersa Valley; the touristic potential of the karstic relief - Izvorul Tăuşoarelor cave.

The methodological system of the research. The undertaken research had the character of a pedagogical experiment in which we conducted a learning activity with the students, which had an immediate practical value and an ameliorative character. The methodological system included: the systematic observation method, the observation method as participant, the pedagogical experiment - as the main method of investigation, the method of analyzing the results of the learners ' activity, the research method of curricular documents and of other school documents, the individual and collective conversation method, the method of tests and other evaluation written tests, logical methods for data processing and interpretation, statistical methods for data processing and interpretation, methods of presenting results.

Conducting the experimental activity. In the observational stage, a docimologic test was applied to assess the students ' prior knowledge about the touristic potential of the Gersa Valley.

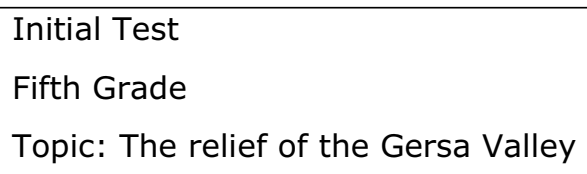

2. At the top of the Gersa Valley lie the Mountains (4 points)

3. A geomorphological phenomenon commonly produced in this valley is....(4 points)

4. The most famous cave in the Gersa Valley is called (4 points)

5. The Mirabilite is ........... (4 points)

SUBJECT II (20 points)

Write on the test sheet the letter corresponding to the correct answer for each of the statements below:

1. The Gersa Valley is bordered to the south by: a. the Rebra Valley b. the Someşul 
Mare Valley c. the Sălăuţa Valley d. the Someşul Mic Valley (4 points)

2. The basin of the river Gersa is located in: a. plain relief; b. a plateau; c. coastal relief ; d. mountain and hill relief (4 points)

3. The Rodna Mountains are a subdivision of $a$. the Oriental Carpathians; $b$. the Western Carpathians; c. the Southern Carpathians; d. the Curvature Carpathians (4 points)

4. The limestones form a kind of relief called: a. glacial; b. karstic; c. fluvial; d. volcanic (4 points)

5. The caves were formed due to the action of: a. ice; b. air; c. wind; d. water (4 points)

\section{SUBJECT III (22 points)}

In the relief of the Gersa Valley landslides frequently occur. Related to this geomorphological process specify:

a. two causes that produce this process. (8 points)

b. two effects of producing this process in the study area. ( 8 points)

c. two measures that can be taken to fight landslides. ( 6 points)

SUBJECT IV (16 points)

Define the following geographical terms: a. valley; b. slope; c. stalagmite; $d$. stalactite.

SUBJECT V (12 points)

Compare the mountain relief with the hill relief of the Gersa Valley indicating $a$ similarity and two differences. The similarities and differences may relate to any of the following: formation, components rocks, altitude, slope, location.

Observation: Full grading will be awarded only if the two types of relief will be comparatively treated and not separately.

All subjects are compulsory. 10 points are granted as bonus. Working time is 45 minutes.

\section{Marking Scheme}

No intermediate scores will be given, except for those explicitly specified in the marking scheme.

Any other correct ways of solving the requirements will be graded, according to the ideas specified in the marking scheme.

SUBJECT I - 20 points. 4 points will be awarded for each correct answer $(5 \times 4=20$ p). 1. Correct answer: north; 2. Correct answer: Rodna; 3. Correct answer: landslides; 4. Correct answer: Izvorul Tăuşoarelor; 5. Correct answer: mineral.

SUBJECT II - 20 points. 4 points will be awarded for each correct answer $(5 \times 4=20$ p). 1. b; 2.d; 3. a; 4. b; 5. d.

SUBJECT III - 22 points. 22 points will be awarded for: a. accurate production of two causes of this phenomenon - 8 points ( 4 points for each correctly stated cause); $b$. mention the two effects of this phenomenon - 8 points (4 points for each); c. enumeration of two measures taken to fight landslides - 6 points ( 3 points for each).

SUBJECT IV - 16 points. 4 points will be awarded for the correct mentioning of each geographic term from points $a, b, c$, and $d$ 
Observation: For the partial definition of geographical terms, the score will be set at half from the initial marking scheme.

SUBJECT $\mathbf{V}-12$ points. 12 points will be awarded for a similarity and two differences between the karstic relief and the fluvial one ( 4 points for each correctly stated similarity or difference; for partially correct answers, 2 points will be given). The similarities and differences may relate to any of the following: formation, components rocks, altitude, slope, location.

Observation: For separate treatment of the two types of relief maximum 6 points are granted ( 2 points for each similarity, as well as for a correctly stated difference).

The students ' results in the initial and final test papers are presented in Table 2 and in Figure 1.

Table 2. The students 'results in the initial and final test paper

\begin{tabular}{|l|c|c|}
\hline \multicolumn{1}{|c|}{ Student } & $\begin{array}{c}\text { Initial test } \\
\text { paper mark }\end{array}$ & $\begin{array}{c}\text { Final test } \\
\text { paper mark }\end{array}$ \\
\hline Student 1 & 5.20 & 6 \\
\hline Student 2 & 5.70 & 7.50 \\
\hline Student 3 & 6.20 & 8 \\
\hline Student 4 & 6.60 & 8.20 \\
\hline Student 5 & 6.80 & 8.40 \\
\hline Student 6 & 7.60 & 8.50 \\
\hline Student 7 & 8.00 & 8.70 \\
\hline Student 8 & 8.40 & 9 \\
\hline Student 9 & 8.60 & 9.60 \\
\hline Student 10 & 9.00 & 10 \\
\hline
\end{tabular}

In the experimental stage, the students were involved in learning activities at the touristic potential of the relief in the Gersa Valley and at the touristic potential of the karstic relief - Izvorul Tăuşoarelor cave. These activities were organized in the field during excursions.

In the final stage, a docimologic test was applied to assess the students knowledge after their involvement in experimental activities.

SUBJECT I (20 points)

Write, on the test sheet, the correct answers which complete the sentences below:

1.The Gersa Valley is situated in the .part of the Someşul Mare Valley. (4 points)

2. At the top of the Gersa Valley a natural touristic attraction is. (4 points)

3. Izvorul Tăuşoarelor cave developed on the rocks called. (4 points)

4. The discoverer of the cave was the teacher......... (4 points) 
5. The gypsum flowers from Izvorul Tăuşoarelor cave are also called.....(4 points)

SUBJECT II - 20 points

Write on the test sheet the letter corresponding to the correct answer for each of the statements below:

1. The Gersa Valley is bordered to the west by: a. the Rebra Valley; b. the Someşul Mare Valley; c. the SălăuţaValley; d. the Someşul Mic Valley (4 points)

2. Izvorul Tăuşoarelor cave was discovered in: a. 1955; b. 1950; c. 1960; d. 1970. (4 points)

3. A form of karstic relief is represented in this valley by: a. cones; b. craters; c. gorges; d. a canyon (4 puncte)

4. Along the Gersa Valley, in areas with limestone rocks the ............ Gruiului; b. Zăpozii; c. Meselor; d. Someşului canyon was formed. (4 points)

5. The longest of the caves below is: a. Zalion; b. Izvorul Tăuşoarelor; c. Măglei; d. Cobăşel. (4 points)

SUBJECT III - 22 points.

Describe the karstic relief from the superior part of the Gersa Valley specifying the following:

a. two external agents that shape limestones. (8 points)

b. two unique features of Izvorul Tăuşoarelor cave. ( 8 points)

c. two names of galleries. (6 points)

SUBJECT IV - 16 points.

Define the following geographical terms: a. meadow; b. minor riverbed; c. mirabilite; $d$. anthodite.

SUBJECT V - 12 points.

Compare the karstic relief with the fluvial relief of the Gersa Valley indicating a similarity and two differences. The similarities and differences may relate to any of the following: formation, components rocks, altitude, slope, location.

Observation: Full grading will be awarded only if the two types of relief will be comparatively treated and not separately.

\section{Marking Scheme}

No intermediate scores will be given, except for those explicitly specified in the marking scheme.

Any other correct ways of solving the requirements will be graded, according to the ideas specified in the marking scheme.

SUBJECT I - 20 points. 4 points will be awarded for each correct answer $(5 \times 4=20$ p). 1. Correct answer: north; 2 . Correct answer: Izvorul Tăuşoarelor cave; 3. Correct answer: limestones; 4. Correct answer: Bîrte Leon; 5. Correct answer: anthodite

SUBJECT II - 20 points. 4 points will be awarded for each correct $(5 \times 4=20$ p). 1 . c; 2. a; 3. d; 4. c; 5. b.

SUBJECT III - 24 points. 24 points will be awarded for:

a. mentioning two external agents that shape limestones - 8 points ( 4 for each correctly stated cause) 
b. mentioning two unique features from Izvorul Tăuşoarelor cave - 8 points (4 points for each);

C. naming two galleries - $6 \mathrm{p}$ (3 p for each).

SUBJECT IV - 16 points. 4 points will be awarded for the correct mentioning of each geographic term from the points $a, b, c$, and $d$

Observation: For the partial definition of geographical terms the score will be set at half from the initial marking scheme.

SUBJECT V - 12 points. 12 points will be awarded for a similarity and two differences between the karstic relief and the fluvial one (4 points for each correctly stated similarity or difference; for partially correct answers 2 points will be given). The similarities and differences may relate to any of the following: formation, components rocks, altitude, slope, location

Observation: For separate treatment of the two types of relief maximum 6 points are granted ( 2 points for each similarity, as well as for a correctly stated difference).

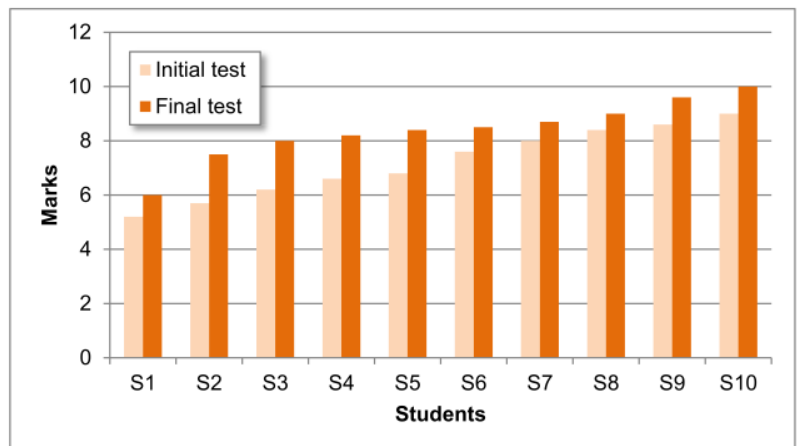

Fig. 1. The students ' results in the initial and final test

Comparing the students ' results obtained in the two tests, we note that the final test results are much better. In the final test, due to the influence of the experimental factor, the results have increased considerably. The arithmetic test grades increased between the initial and the final test (Table 3), from $\mathbf{7 . 2 1}$ (with a dispersion $\Delta=1.52$ ) to $\mathbf{8 . 3 9}$ (with a dispersion $\Delta=1.12$ ). The difference between the two arithmetic grades being 1.18 this means an improvement of $16 \%$. In the experimental group, the standard deviation decreased by $12 \%$ (from 1.23 to 1.05 ), thus reflecting the increase of the homogeneity of the experimental group by the same percentage.

Table 3. Statistical interpretation of students ` marks

\begin{tabular}{|c|c|c|c|c|}
\hline & $\begin{array}{c}\text { Final marks } \\
(\mathrm{m})\end{array}$ & $\begin{array}{c}\text { Square marks } \\
\left(\mathrm{m}^{2}\right)\end{array}$ & $\begin{array}{c}\text { Dispersion of } \\
\text { marks } \\
\left(\Delta=m-m^{2}\right)\end{array}$ & $\begin{array}{c}\text { The square } \\
\text { standard deviation } \\
(\partial=\sqrt{\Delta})\end{array}$ \\
\hline Initial test & 7.21 & 53.50 & 1.52 & 1.23 \\
\hline Final test & 8.39 & 71.15 & 1.12 & 1.05 \\
\hline
\end{tabular}




\section{DISCUSSIONS}

1) Analysing the content of the scientific-methodical paper with the title "The Touristic Potential of the Gersa Valley and Its Exploitation", for obtaining the first teaching degree.

We notice that the paper is coherently structured in seven chapters. In five chapters, the touristic potential of the Gersa Valley is analyzed, a chapter presents the conducted pedagogical research and a chapter is devoted to conclusions.

Analyzing the structure of the chapter Methodological applications on "The Touristic Potential of the Gersa Valley and Its Exploitation", we note several aspects. In the first stage, an observational investigation is carried out using the test method, a docimologic test is given to obtain information about the students ' knowledge on the topic. In the second stage, an experimental research is performed in which the students studied two content items. In the postexperimental stage, a test is given to highlight the students ' progress through their involvement in learning activities organized throughout the experiment.

2) Analysis of the conducted pedagogical research. From the analysis of the research presentation, we note other aspects. The research is longitudinal because it analyzes the results of a group over a longer period of time (Popa et al., 2009, p. 20). Since we intervened on the group's involvement in an educational program, it was necessary to have a control group to make sure that the effects obtained are due to the intervention and not to other external factors. We have not involved a control group in the research because in rural areas we did not have other students in the fifth grade. For the same reason we have not done any sampling of subjects, but we included in the research all available students.

The undertaken pedagogical research is applicative because we sought to investigate through scientific methods a domain of the educational field studying at geography - with the purpose of knowing it and its optimization (Popa et al., 2009, p. 19).

This research is quantitative. We used counting to highlight how many subjects responded to a question and to how many items a subject answered. We also used measurement by which we assigned numerical values to some characteristics of the studied phenomenon, in this case the students' level of knowledge about the touristic potential of the Gersa Valley.

The research paradigm was constructivism. The research strategy was the research-action. 


\section{CONCLUSIONS}

At the end of this study, we reached several conclusions:

1) The content of the scientific-methodical paper for obtaining the first teaching degree under the title "The Touristic Potential of the Gersa Valley and Its Exploitation" contains six chapters, one of which is dedicated to the conducted pedagogical research.

2) Detailing the chapter Methodical applications on the topic "The Touristic Potential of the Gersa Valley and Its Exploitation" can be used by teachers of geography in pre-university education to guide themselves in the design, organization and presentation of pedagogical research.

3) The presented pedagogical research is an applicative, quantitative pedagogical one, with an observational stage and an experimental one. The research paradigm was constructivism. The research strategy was the research-action.

\section{References}

Băban, A. (2002). Metodologia cercetării calitative. Cluj-Napoca: Presa Universitară Clujeană.

MECTS (2011). Appendix: Methodology from 7 October 2011 regarding the training of the staff in pre-university education, http://www.ub.ro/files/facultati/dppd/program-formarecontinua/omects5561_2011.pdf, Accesat în 20 iulie, 2014.

MECTS (2011). Law of National Education, București. www. edu.ro

MECTS (2011). Order no. 5561 from October 2011 for approving the Methodology regarding the training of school education staff. www.edu.ro

Popa, N. L., Antonei L., \& Labăr A. V. (2009). Ghid pentru cercetarea educației. Iași: Polirom Publishing House. 